\title{
Leisure Providers and Consumers: A Case of Art of Living
}

\author{
Madhu Nagla \\ Department of Sociology, Maharshi Dayanand University, Rohtak, India
}

\section{Email address:}

bnagla@gmail.com

\section{To cite this article:}

Madhu Nagla. Leisure Providers and Consumers: A Case of Art of Living. Humanities and Social Sciences. Vol. 6, No. 1, 2018 , pp. 1-6. doi: 10.11648/j.hss.20180601.11

Received: September 18, 2017; Accepted: November 14, 2017; Published: March 5, 2018

\begin{abstract}
Leisure in public life has declined, however, the commercialization of leisure and recreation is catching up at fast speed. In the contemporary time, on the one side, we find that leisure and recreation is around family or in the intimate association. On the other hand, people are more and more engaged with television, video games, computers, ipads, internet, chatting devices. The entertainment and leisure activities with the electronic devices are more of a commercializing in its nature. At the same time people are also in search of leisure moving towards visiting Ashrams which are providing "Art of Living". Vast numbers of people are regularly visiting Ashrams at different places. This activity has also enormous growth and commodification and becoming popular in world and particularly in India. It is not only becoming popular among the old age people but also becoming popular among the younger lot also. Going out in the Ashrams for "Art of living" is also more relying on market principles. Thus, in the present paper we will discuss about the consumers of leisure i.e. people who are learning "art of living" and providers (Gurus in Ashrams) of leisure. For this we will focus on some of the specific selected "Ashrama" and look into their consumer based various activities.
\end{abstract}

Keywords: Leisure, Art of Living, Ashramas, Providers, Consumers

\section{Introduction}

The decline of public life, commercializing leisure and recreation; formalizing recreation: Organizations over spontaneity are the three developments that have brought about the change in leisure time. The decline of public life is a development in which Richard Sennett argues that modernity has seen the fall of public man, as people more and more seek refuge in the ties of family or intimate association [1]. Leisure has been affected in far-reaching ways. Migration to the suburbs and the progression of the television keeps people homes, video games, DVD players, personal computers, ipads, internet are also to be counted. The second development is commercializing leisure and recreation. This development has made an outstanding mark on our leisure time more than any of other two developments. Recreational activities were so that people could have fun; instead many new purchase services and goods. An enormous growth of commodification has populated in the world. Commodification makes it possible to buy and sell peculiar goods for service. Staying home to enjoy a performance in front of our home entertainment centre has become the norm.
Recreational shopping is another example that has sky rocketed. Going to the Ashrams and to the places for art of living is becoming another important activity which is rapidly catching not only in India but also world at large.

Tourism, eating out, going to cinema are the major leisure activities on which people spend, however, there are other industries which are spreading rapidly, but are ignored, or they are invisible in the literature on leisure. Visiting Ashrams has become quite common for many people in the Indian context. Therefore, we have decided to explore the various facets of ashrams where the leisure, religious aspects and other events are becoming quite common.

Leisure role in people's lives is not purely economic. Leisure has important social, psychological and cultural dimensions. As leisure's share of the economy grows, so does its role in people's everyday lives. So the balance tilts from life being work- and production- centred to becoming leisureor-consumption centred. Leisure becomes an alternative or complementary source of identities (who people think they are, and how others see them). It is not leisure goods, activities or services themselves which confer identities. They come from the meanings which become associated with them in the course of all the marketing, embellishment in 
media coverage, and in everyday social intercourse. The leisure industries do not supply just goods and services. They also market desires, and enable consumers to be recognized as- and to fell like- particular kinds of people as a result of what they wear, eat, drink, what they listen to and watch, and where they are seen and who they are seen with. The leisure industries do not create social class, age, gender, ethnic or national divisions, but they can sharpen, deepen or diminish these divisions, and characterize the relevant groups. They do this by deciding which market is most appropriate for a given identity. Without this necessarily being anyone's conscious intention, it has been argued that collectively the leisure industries convey an impression that black people are particularly talented in sport and entertainment [2]. In a singular way, tourism has been accused of stereotyping third world people as 'happy servants' of consumers from richer countries [3].

Leisure, as we know it today, arises when three conditions are met [4].

1. First work must be modernized, meaning that it must be compartmentalised- separated from the rest of life by some combination of time, place and social relationships- and rationalised- organised so that task are performed as efficiently as possible and with no incentive to maximize job satisfaction. Opportunities to do things for the pure pleasure, for intrinsic satisfaction, thereby become concentrated within people's 'own' time.

2. Second, the family, community and religious controls that once prescribed entire ways of life must be relaxed. The moderation of work, which led to individuals receiving money wages, assisted this relaxation. In preindustrial times both work and recreation were normally part and parcel of family and community life [5] whereas modern leisure allows- indeed requiresindividual and households to make lifestyle choices.

3. Third, people must be free to form associations for religious, political and recreational purposes, and business must be able to market leisure goods and services. Such provisions will only be made when people have fun time and money to spend, but this in itself is not a sufficient condition to produce modern leisure. There must be space for diverse uses of leisure to be offered. People can select and act on leisure interests, thereby making lifestyle choices, only when a wide range of provisions are 'out there' rather than interwoven in their family and neighbourhood.

Societies consist of men, woman, and children and of various age groups. If these components are not present there can be no society. They make up society collectively. Our society responds differently to recreation and leisure and in turn so do the individuals. The individuals play an important part of how they function in society and how they react to recreation and leisure. The way in which we perceive our roles in society impacts on our recreational and leisure activities. We must consider the way in which we as individuals and our society come together in terms of recreation and leisure. As individuals we need to ensure that our roles in society impact positively. Society in general does not consider the impact of their roles and how it affects leisure. They both are two different entities but function together.

\section{Leisure and Art of Living}

Now-a-days when people talk about various leisure activities, spiritualism is regarded as one of the most important leisure activity. If somebody is interested in undertaking a spiritual journey, then, India is the perfect place to enjoy it. There is dearth of some of the most distinguished spiritual gurus, yoga gurus and ashrams in India. Some ashramas teaches yoga, some takes you on a soul satisfying spiritual journey and some to the teaching of art of living. Even though the technique is different, all the Indian ashramas have the same aim i.e., make people spiritually aware and contribute to the social good. Godbey wrote recreation and leisure behaviour is ultimately infinite, nonrational, and full of meaning which is, or can be, spiritual [6]. Goodale state that "leisure must be filled with purpose, compelled by love, and wrapped in the cosmic and the spiritual [7]. Howe-Murphy and Murphy suggested that the leisure experience is characterized by a mystical or spiritual feeling of being connected with oneself, with all else, and a sense of oneness with the universe [8].

Discussion of leisure and spirituality is not only about the close association between leisure and spirituality but now it also includes wide range of recreation and leisure activities like therapeutic recreation, camping, recreational management, outdoor/experiential/adventure/environmental education, tourism and community recreation [9]. In addition there is increasing interest toward the 'art of living' and leisure. A research paper by Zubin Mulla, at Tata Institute of Social Sciences, says that SudarshanaKriya, a breathing technique prescribed by The Art Of Living, reduced stress in 72 managers. However, there is no empirical sociological research to see the relationship between leisure and 'art of living'. However there are couple of studies in India on yoga and leisure, which brings out the frequency of leisure among women in yoga participation and their level of satisfaction and which in turn has provided them freedom [10]. Women's participation in yoga leisure participation is found to be positively correlated with perceived wellness and other benefits. Ragheb [11] and Heintzman and Mannell [12], Heintzman [13], Schmidt and Little [14] in their studies have explored various dimensions of spiritualism in relation to leisure activity.

\section{Art of Living Foundation}

Art of living is all about leading a normal and enjoyable life amidst all the tensions and stresses that inundate living today. It is more of a technique through which we learn to eliminate strains. 


\subsection{The Essence of Being Human}

The art of living gives you idea about the essence of being human. It speaks about humanness, gentleness, putting yourself out on behalf of others, being vulnerable. It embraces compassion and toughness. It recognises that my humanity is bound up in ours, for we can only be human together.

\subsection{The Truth Works}

Art of living suggests that when the life works betterwhen drama and chaos get tiresome, and goodness and peace and preferred companions, then one receives messages from the truth. When one is naturally happier, stronger, and more deeply engaged with people and place, one assumes that he or she is close to the truth.

\subsection{In-touch with Reality}

A sign of progress is when you no longer fight the nature of life. Instead, you work with it. You stop pretending that life is supposed to be a certain way and accept it on its own terms. You size up the human story and get on with living.

\subsection{Honesty Is an Aphrodisiac}

Art of living pays to be honest. It pays in rewarding relationships. It pays in unblocked energy. It pays in passion. To stand tall in who you are, unafraid to reveal what you want and need, kind enough to tell the truth, and brave enough to bear the consequences, is a telling sign of spiritual development.

\subsection{Suffering Is Our Fear of Pain}

There will always be pain in our life. This is something we learn as progress spiritually. We also learn that if we resist pain, if we fear it, then we create additional pain called suffering. Our resistance to pain stands between us and fullbodied living; it keeps us at war with our problems and from making peace with life's dual nature. When pain arises in your life and you stand that you making progress on the path.

\subsection{Interdependence of Humanity}

Art of living helps in becoming more and more aware of the interconnection of all beings, creatures, and elements. A declaration of life's interdependence is a sign of spirit.

\section{Methods}

Moving from question of what is leisure to exactly who has leisure raises real problems for leisure research. What is 'art of living'? How 'art of living' can means of deliverance from fatigue and mental tension? How can a choice of 'art of living' turn out to be healthy and leisure benefitting? The main purpose of the present paper is to understand the involvement of individuals in learning 'art of living' as a leisure activity which in turn benefits to their mental peace and also in keeping good health. The data in this paper are drawn from interviews with people, who accidently met researcher at different places on different occasions between the periods of March 2015 to October, 2015. The researcher could able to establish contact with them afterwards as they attend some of the courses of 'art of living' in different ashramas. We approached many of them but could interview only 20 of them and had their indepth-interviews. Relevant ethnographic interviews of narrative experiences about their experiences in Ashram were extracted and analysed for the study. The justification for examining leisure providers lies in the increasing number of centres of art of living and the people who are the consumers of their activities.

\section{Providers of Art of Living Courses}

In the ensuing section we will discuss the different ashrams where 'art of living' in form of recreation and leisure is practiced.

India has always been a popular destination with spiritual seekers who flock to the country's many ashrams. The Shrimad Rajchandra Mission Dharampur in Himachal Pradesh offers corporate programmes through customised visits to the Ashram as residential retreats. Pidilite Industries, Calyx Pharma, Jasani Group, Orbit Life sciences, and Diatrend are some of its clients. Yogi Ashwini of Dhyan Foundation has been training managers for 15 years. His ashram says its programmes help them in improving their looks and glow, de-stress and decongest emotionally. It claims to have trained employees of Metlife, Wipro, Cisco, Hewlett-Packard, HCL, Infosys, IBM, ITC Hotels, TCS, Videocon, and Tata Steel [15]. Every ashram is different though, so which one to choose? The people to whom we interviewed had experiences of going to different Ashramas and their number is six. Below, we are presenting the analysis of people's experiences of leisure in the Ashrams.

\subsection{Sri Sri Ravi Shankar's Art of Living Ashram}

This Ashram is founded in 1982 by Sri Sri Ravi Shankar, The Art of Living is renowned world-wide for its stresselimination and self-development programs based mainly on breathing techniques, meditation and yoga. The Art of Living as a voluntary organization also undertakes various initiatives aimed at uplifting humanity and enhancing the quality of life. The foundation course at the ashram is the three day Art of Living Part I residential workshop. One learns revitalizing breathing techniques to restore the natural rhythms of body and mind. It is situated in the Panchagiri hills, 36 kilometers southwest of Bangalore, near Udipalya village. It offers the courses on Art of Living I \& II, yoga, meditation, Vaastu Shastra, Vedic math, and youth training courses. Sri Sri Ravi Shankar's The Art of Living started conducting corporate training 14 years ago. It now is in great demand, withy upto 200 programmes a year. Its clients range from Google to Larsen and Toubro, Mahindra and Mahindra to Accenture, Tat Motors to Barclays Bank. It is not the usual training for managers, but it is spread over two days. It teaches how to manage yourself not to others. "Companies have realised that 
people at all levels have to learn to manage themselves before they can manage others" says one of the spokespersons for the Art of Living.

\subsection{Osho Ashram}

Osho was perhaps India's most controversial spiritual leaders due to his views about sex. The Osho ashram no longer holds workshops calling for undressing, and free love isn't encouraged. Yet, unlike many ashrams, there's no gender segregation anywhere at the Osho ashram. The ashram, which is more like a resort, aims to provide a luxurious environment where people can be at ease with themselves. Despite the compulsory wearing of maroon robes, it's commercial and far removed from Indian culture. Courses are mostly directed at healing from traumatic experiences, rather than personal development. It is situated in Pune, Maharashtra (4 hours from Mumbai). It offers the courses on Active meditations (including jumping and screaming), Tantra workshops, plus a huge range of multi-diversity courses.

\subsection{Isha Foundation Ashram and Yoga Center}

The Isha Foundation is a non-profit organization, founded by Sadhguru JaggiVasudev in 1992. Its purpose is to foster people's spiritual and physical wellbeing through yoga and outreach programs, such as environmental rejuvenation. The core of the Foundation's activities is a customized system of yoga called Isha Yoga. The 3-7 day introductory program, known as Inner Engineering, introduces guided meditations and a powerful inner energy process for deep inner transformation. It is called Isha Yoga Center, at situated at the base of the Velliangiri Mountains in Tamil Nadu. The courses offered are: Inner Engineering, Hatha yoga, yoga for children, advanced meditation programs, sacred treks, and mind and body rejuvenation retreats based on Ayurvedic principles. Isha foundation conducts programmes of 90 minutes to seven days that promise to impart leadership skills through yoga.

\subsection{Satya Sai Baba Ashram}

The basic teachings of Sathya Sai Baba, widely recognized by his mop of black hair, focus on belief in God, living a moral life, and helping other people. The spiritual leader encourages devotees to follow the religion of their choice and/or upbringing. People are drawn to the ashram by the desire to see and be healed by an "incarnation of God". However, the rules are strict, so do be prepared to follow them. The main ashram (Prasanthi Nilayam) where Sathya Sai Baba mostly resides is in Puttaparthi, 125 kilometers northeast of Bangalore. The Courses are on Ashram life consists of pathways to God devotion, including early morning Vedic chanting, singing of religious songs, spiritual talks, and discussions.

\subsection{Mata Amritanandamayi Ashram}

Amritanandamayi is known as "Hugging Mother" or
"Amma". She is regarded as spiritual leader, humanitarian and social worker. She is regarded as the Mother of All. Mata Amritanandamayi Devi envelops devotees with her love. She focuses her attention on trying to overcome the lack of love and compassion in the world, and devotees are particularly attracted to her for her comforting embraces. Free public darshans (audiences) are held with Amma at around 10 a.m. on Wednesdays, Thursdays, Saturdays and Sundays. The Amritapuri Ashram is in Kollam, Kerala which is 110 kilometres north of Trivandrum. It offers the Courses on Integrated Amrita Meditation Technique (a 20 minute combination of yoga, pranayama, and meditation). Morning and evening mediation, prayers, and service are all part of the ashram life.

Mata Amritanandamayi concludes her programmes by embracing each person attending the events to bestow her unconditional love on people from all walks of life. The people who come in contact with her, she offers them emotional solace, spiritual guidance, and concrete solutions to their problems. In this way, this simple yet powerful act as a mother's embrace- has become both catalyst and symbol for the growing international network of humanitarian initiatives that are embracing the world.

\subsection{Sri Aurobindo Ashram}

Founded in 1926 by Sri Aurobindo and a French woman known as The Mother, the Sri Aurobindo Ashram has grown into a diversified community with thousands of members. The ashram sees itself as working towards the creation of a new world, a new humanity. If you're looking for a quiet haven of retreat, this isn't the right ashram for you. It's "a vibrant centre of life in a modern urban setting". There's no renunciation of the world there. Everyone spends time each day in one or another of the Ashram's 80 departments. The Ashram is located in Pondicherry, 160 kilometres south of Chennai, in Tamil Nadu. Collective meditations are held, but there are no prescribed practices, rituals, compulsory meditations, or systematic instructions in the Ashram.

\section{Discourse About Art of Living}

The Art of Living has proliferated in all parts of India and world as a whole. No one is ready to talk on record about the money involved, but the Delhi-based trainer of one such outfit says a programme for 25 managers can cost you more than Rs. 3 lakh. In fact, Banglore has a Corporate Guru, otherwise as Swami Sukhabhogananda. He talks about his ability to apply spiritual truths to the management paradigm through talks based on "World Belief Systems such as Buddhism, Hinduism, Sufism, Christianity and others to address relevant questions of organisational challenges. That is why the epithet.

On the basis of our in-depth interviews about the experiences they shared with the researcher are presented below in the form of narrative analysis. The narratives are about the leisure which people have experienced in the form of art of living. 
Myself, my husband and my two sons we were living very happily. On one black night, I lost my both of sons in car accident. I was really stressed out, not able to lead a normal life. I loved my sons so much that $\mathrm{i}$ was unable to move forward in my life and forgetting them even for an hour. I told my husband that it is very difficult for me to live without them. He took me to Sri Aurbindo Ashram in Pondicherry, South of India. The place was full of peace and fascinating location. I got some solace as soon as I saw myself close to the nature and started enjoying it. My life transformed as soon as I joined the course of 'art of living' practiced in the ashram. As I endeavour to reflect on the spiritual path transcend in the yesteryear, there arises confusedly and paradoxically within my mind the ideas of vast mental power of caution, of penuriousness, of coolness, of malice, of triumph, of merriment, of supreme despair, of supreme longing. I never thought of it that my life will back in the normal routine. It has not only brought me in the normal routine but also helped me to inspire other people who pass with some of miseries in their life.

As a shared pattern across all these accounts of experiences in ashrmas after attending 'art of living' seems to be bring a customised mix of tranquilly and adventure. The physical of travel, along with the loss of social coordinates, creates a visual narrative based on emotional stimulation and disruption of mundane. I am a single unmarried female of 45 years. I had lot of responsibilities in the family to take care of my old age parents and my younger sisters and brother. I never had chance to go out. I was tired throughout all year serving my parents and sisters and brothers. I went to Isha foundation Ashram at Velliangiri Mountains in Tamil Nadu. I was struggling with the battle inside and outside. The 'art of living has taught me to relate to love everyone and unconditionally. I feel so free and complete as if I have reunited myself.

I am a divorcee and living with my daughter. I had no direction for what to do. My mother pushed me to go to Sri Sri Ravi Shankar's Art of Living Ashram in Banglore. I went there and she took care of my daughter when I was attending that course of 'art of living'. My life was defined by strange idiosyncrasies- obvious to the existence of others, strongly preferring solitary activities, avoiding interacting in groups, problems in expressing emotions and understanding social cues. My life was in a whirlpool for thirty years; a cry within that needed a release, a talent or rather talents that needed to manifest. How, where, when, there was no idea. 'Art of Living' course has taught me to restore my confidence in my talent. Today, I am a successful women and helping others also to rebuild their lost confidence.

Walking the spiritual path can be a tricky adventure. Sometimes I make progress and become more free and loving and wise; sometimes I may think my mediation or prayer or ritual is leading toward enlightenment, but really I am just reading water or even going backwards.

In contrast to the functional aspect of Art of Living, some people are also critical of experiences which they had during their visit to the Ashrmas.
One of the respondent reported that most of the people who come in Osho Ashram are from higher middle class or higher class background. Donation is huge. The flood of money is partly a function of the huge rise in disposable income that many Indians now enjoy, but some sociologists say it reflects a need to balance newfound wealth with oldfashioned values. They look at renunciation, asceticism, a life of simplicity as a higher ideal, but that is an ideal hardly anyone can live up to with this growing wealth. Giving ends up doing the balancing act for them. The Osho ashrama's luxurious environment where people can be at ease with themselves.

There is another couple who went to the Ashram of Mata Amritanandamayi and shared her experiences. They find that publicity for this Ashram is too much but we did not find anything new. People are there to just get a chance to be hugged by mata. If they do not get chance to be hugged, they further become depressed. Free darshans are specified only on certain times and certain days. For common people it is difficult to have accessibility for darshan for which they come here. Thus, in all they have made it a important episode of hugging and by getting it leads to further frustration and aggression. The couple also reported that these ashram people are engaged in making their activities as scarce commodity, so to attract people for their unique identity. For this ashram the 'personal hugging is an important activity.

\section{Sociological Discussion}

Changes are taking place in class status, gender roles, material wealth and structure of society. These above discussed Ashrama in the capitalistic society are working as the providers of 'art of living' as their product. Individual who feels unable to control the uncertainty of his life is more likely to believe in those who promise to help him gain some measure of control becomes the consumer of this product.

Sociologically speaking the slow weakening of organised religion has left a vacuum that wily god-men with their magnetic attraction by providing luxurious environment along with some solutions are rushing to fill that gap.

The rapid communication channels give its viewership what it wants. This perhaps explains the alacrity with which channels of every sort gave over large chunks of their programming to paid shows from godmen who promise miraculous solutions for everything from romantic failure to ridding a home of ghosts. Most disconcertingly, even educated followers seem to be willing to accept such claptrap. The sight of these supposed godmen amassing wealth, travelling in luxury SUVs, displaying an inordinate fondness for expensive watches and developing ashrams that look like spiritual Disney lands, strangely, does not seem to disgust them or make them aware that this brand of spirituality is a business worth over Rs. 1,0 billion annually.

If the media is a mirror to society then perhaps the slow withdrawal of mainstream television channels from this space is a sign of things to come. NK Singh, secretary of the Broadcast Editors Association admits television's flirtation 
with bizarre godmen has "exacerbated irrationality in society". He adds: "Two years ago, channels had five to seven such shows. In the last six months, all the national channels including AajTak, Star TV, IBN-7 and Zee have removed babas from their prime-time slots and are refraining from featuring them on religious occasions." Even India TV seems to have seen the error of its ways. "From half a dozen such shows, we're down to a single astrology one in the morning slot," says Vinod Kapri, the channel's managing editor.

People are gullible when they are vulnerable. Once they are shown the other side, they are willing to see. Godmen will continue to exist as long as people seek god. Reformistwriter Asghar Ali Engineer sees superstition as a complex phenomenon with political patronage being a strong factor. "Sai Babas and Nirmal Babas will come and go. The unique reason why superstition thrives in India is because of the absence of a communion. People view these god-men as their 'personal agents of god', who intercede on their behalf. The godman becomes a magician. A magician has clients. Indians look at them as 'elevated magicians'. Television has only catered to this, not been the sole reason," adds sociologist Dipankar Gupta.

For the many babas who have grown rich on the strength of their bizarre claims that can only be good news.

But their popularity is more an expression of "the extraordinary religiosity of the Indian people, which has withstood the focus of education and modernization", said historian Ramchandra Guha. "It's manifestation is the offering of money and jewels to a deity whether living or frozen in stone."

\section{Conclusion}

The case of art of living as a leisure activity has opened doors for many people to become consumers of this rapidly expanding industry with different customers. Nevertheless, when we look closer, the situation is not so simple to explain as there is a deep and intense interaction between modern capitalism where the relationship are at the cross roads. People do not have time to listen to the problem of other person. In this situation, they look toward the market, where the providers of 'art of living' leisure are ready to sell out their product. In turn receivers are also ready to accept the package of art of living which gives them relief and gives a opportunity to begin their life in more of a liberated and human touch manner. The providers understand the pulse and expectation of the people and in turn they prepare the packages of leisure activity like 'art of living' according to the expectation of masses. This paper calls for a critical and contextual perspective to understand the dynamic emergence of new forms of life styles of consumerist societies, emphasizing a future agenda of further research that is sensitive to the complexities of desires and leisure activities of distress people in the country from different background. The ashrams are also in constant challenge to ensure that the services and experiences they offer look unique, original and fresh to consumers which will attract more and more people. It is just like a free market in capitalistic society where there is a competition and the providers want to earn maximum profit by selling their packages to the consumers.

\section{References}

[1] Richard Sennett, The Fall of Public Man, Cambridge: Cambridge University Press, 1977.

[2] E. Cashmore, Black Sportsmen, London: Routledge, 1982.

[3] Nigel Morgan and Annette Pritchard, Tourism Promotion and Power: Creating Images, Creating Identities, Wiley, 1988.

[4] Ken Roberts, The Leisure Industries, New York: Palgrave Macmillan, 2004.

[5] R. W. Malcolmson, Popular Recreations in English Society 1700-1850, Cambridge: Cambridge University Press, 1973.

[6] G. C. Godbey, The Future of Leisure Services: Thriving on Change, USA: Venture publishing House, 1989.

[7] T. L. Goodale, "Legitimizing Leisure a New", Paper presented at the Scholarly Presentation portion of the $25^{\text {th }}$ Anniversary of the Leisure Studies Department, Ottawa: University of Ottawa, 1994, May 14.

[8] R. Howwe-Murphy and J. Murphy, "An Exploration of the New Age Consciousness paradigm in Therapeutic Recreation", Philosophy of Therapeutic Recreation: Ideas and Issues, 1987,1, pp.41-54.

[9] P. Heintzman, "Leisure and Spiritual well-being relationship: A Qualitative Study", Society and Leisure, 2000, 23 (1), 4169.

[10] [10] Madhu Nagla, "Yoga, Health and Leisure: Attitudes of Women in Haryana", World Leisure Journal, 2006, Volume 48, No.2.

[11] M. G. Ragheb, "Leisure and Perceived Wellness: A Field Investigation", Leisure Sciences, 1993, 15, 13-24.

[12] P. Heintzman and R. Mannell, "Leisure Style and Spiritual well-being" in W. Stewart and D. Samdahl (eds.), Abstracts from the 1999 Symposium on Leisure Research (p.68). National Congress for Recreation and Parks, Nashville, TN, 1999, October 20-24.

[13] P. Heintzman, "Leisure and Spiritual well-being relationship: A Qualitative Study", Society and Leisure, 2000, 23 (1), 4169.

[14] C. Schmidt and D. E. Little, "Qualitative Insights into Leisure as a Spiritual Experience", Journal of Leisure Research, 2007, 39 (2), 222-247.

[15] Hindustan Times, "Babas to the fore, Yoga, Spirituality takes centre stage in Corp Training", 2015, $26^{\text {th }}$ December. 